\title{
Linguistic features of speech acts of praise and criticism in English pedagogical discourse (based on genre "Lesson")
}

\author{
O. V. Dudina \\ Donetsk National Medical University, Kropyvnytskiy, Ukraine \\ Corresponding author. E-mail: rexiff@ukr.net
}

Paper received 21.02.20; Accepted for publication 20.03.20.

https://doi.org/10.31174/SEND-Ph2020-225VIII67-04

\begin{abstract}
The article is devoted to the study of the lexical and grammatical features of speech acts of praise and criticism in contemporary English-language pedagogical discourse. It is identified the means of verbalizing evaluating communicative strategy of pedagogical discourse through continuous examine of vocabularies and communicative analysis of texts of English language lessons. We found out the frequency of using the speech acts of evaluating and controlling communication strategies at English lesson.

Keywords: speech act of praise, speech act of criticism, evaluating communicative strategy, pedagogical discourse, English lesson, communicative roles.
\end{abstract}

Problem Raising. A lesson as a communicative event consists of a set of communicative strategies used by the teacher, which include 4 stages: organization, control, explanation, completion, and include the dominant purpose - knowledge transfer. During any type of a lesson, a teacher uses a variety of CSs, namely organizing, evaluating, explaining, and controlling. According to prof. F. S. Batsevich, by a speech act, we mean the minimum unit of organization of the language code in communication, purposeful speech action carried out in accordance with the principles and rules of speech behavior adopted in a certain discursive community, the minimal unit of speech. [1, p. 170].

The analysis of the recent research works and publications. Researchers as F. S Batsevich, V. I. Karasik, G. G. Pocheptsov, V. Littlewood studied a set of speech acts that uses a speaker to realize their communicative intentions $[5 ; 6 ; 7 ; 8]$. Linguists have presented different classifications of speech acts, characterized their individual groups, and examined both grammatical and lexical features of speech acts. However, despite the results obtained, this problem cannot be considered as solved. It is the communicative and linguistic features of the Englishlanguage pedagogical discourse that have not yet been comprehensively covered in specialized literature.

The peculiarity of pedagogical communication is the need to maintain interest in learning, to acquire knowledge [2, p. 16]. This causes an English teacher to use a large number of speech acts of praise and criticism that stimulate and motivate a pupil to a particular activity.

The aim of the article. The aim of the article is to clarify the specifics of speech acts of praise and criticism in English-language pedagogical discourse by analyzing their vocabulary characteristics.

The exposition of the main material. The study material covers a body of 200 speech acts of praise and criticism selected from the observation of video samples of English lessons. The object of study is the speech acts of praising and criticism in the process of implementation of English-language pedagogical discourse. The subject of the analysis is the specificity of lexico-grammatical and national-cultural aspects of expression of criticism and praise in the English pedagogical discourse.

According to the chosen research paradigm, firstly, we characterize the speech acts of praising that are used in the material observation. In terms of describing the lexical composition of such speech acts, it is necessary to find out the most frequent words and phrases from which they are constructed in English-speaking pedagogical discourse. A solid survey of the English language video recording, videos allowed us to distinguish the following lexico-phraseological exponents of speech acts of praising: good (27\%), well done (8.75\%), nice (7\%), very nice (7\%), correct! (5\%), right! (4\%) and others.

The core of vocabulary and phraseological means of registration of the investigated speech acts $(72.35 \%)$ are the following units: Good !, Well done !, Nice !, Very nice! That's correct !, All right !, Very good!, I like!, Right!

The periphery of the corpus of lexico-phraseological exhibitors includes: Great!, You tried hard!, Beautiful!,

\begin{tabular}{|l|l|l|l|}
\hline № & $\begin{array}{l}\text { Speech acts of } \\
\text { praising }\end{array}$ & $\begin{array}{l}\text { Absolute } \\
\text { frequency }\end{array}$ & $\begin{array}{l}\text { Relative } \\
\text { frequency }\end{array}$ \\
\hline 1) & Good! & 30 & $27 \%$ \\
\hline 2$)$ & Well done! & 9 & $8,75 \%$ \\
\hline 3$)$ & Nice! & 8 & $7 \%$ \\
\hline 4$)$ & Very nice! & 8 & $7 \%$ \\
\hline 5$)$ & That's correct! & 6 & $5 \%$ \\
\hline 6$)$ & All right! & 5 & $4,4 \%$ \\
\hline 7$)$ & Very good! & 5 & $4,4 \%$ \\
\hline 8$)$ & I like ...! & 5 & $4,4 \%$ \\
\hline 9$)$ & Right! & 5 & $4,4 \%$ \\
\hline 10$)$ & Very interesting! & 4 & $3,7 \%$ \\
\hline 11$)$ & Wonderful! & 4 & $3,7 \%$ \\
\hline 12$)$ & Excellent! & 4 & $3,7 \%$ \\
\hline 13$)$ & Perfect! & 4 & $3,7 \%$ \\
\hline 14$)$ & Fine! & 4 & $3,7 \%$ \\
\hline 15$)$ & Great! & 3 & $3 \%$ \\
\hline 16$)$ & You tried hard! & 2 & $2,65 \%$ \\
\hline 17$)$ & Beautiful! & 1 & $0,7 \%$ \\
\hline 18$)$ & Wow! & 1 & $0,7 \%$ \\
\hline 19$)$ & That's it! & 1 & $0,7 \%$ \\
\hline 20$)$ & Absolutely! & 1 & $0,7 \%$ \\
\hline 21$)$ & That's incredible! & 1 & $0,7 \%$ \\
\hline & Total & $\mathbf{1 1 1}$ & $\mathbf{1 0 0 \%}$ \\
\hline & Core (1-9) & $\mathbf{8 1}$ & $\mathbf{7 2 , 3 5 \%}$ \\
\hline & Main part (1-14) & $\mathbf{1 0 1}$ & $\mathbf{9 0 , 8 5 \%}$ \\
\hline & Periphery $(15-21)$ & $\mathbf{1 0}$ & $\mathbf{9 , 1 5 \%}$ \\
\hline
\end{tabular}

Wow!, That's it!, Absolutely!, That's incredible!

Table 1. Lexical exponents of English speech acts of praising in pedagogical discourse 
The most common lexical fillers of speech acts praising are adjectives such as: good, nice, wonderful and phrases: well done, that's correct, all right. Less used are adverbs: absolutely, fine, right, and exclamation: wow.

Speech acts of praising are characterized by a great variety and lack of pattern. There is no specific vocabulary assigned to it, there are widely used synonyms, slang, colloquialisms, idioms. According to the continuous examination of phraseological dictionaries [3, p. 87]:

- Apple of one's eye = a person or thing that is precious or loved above all else. For example: "You are the apple of my eye!"

- To the hilt = with a lot of effort or to the extreme. For example: "You really prepared for the hilt for today. Good of you!"

- Blue ribbon = first prize. For example: "Peter's science project won the blue ribbon because it was the best in the contest."

- Burn the midnight oil = to stay up late at night studying or working. For example: "You're probably burnt the midnight oil, as I see. Your answer is excellent!”

- Cream of the crop = the best. For example: "You are the cream of the crop!"

- Go over with a bang = to be extremely successful. For example: "You always go over with a bang!".

- Go overboard = to do too much. For example: "You've gone overboard for today! I'm proud of you!"

- Good egg = a person who is basically good or sound. For example: "You're really a good egg!"

- Heavyweight = a leader in a particular field. For example: "You are a real heavy weight!"

- Hit the nail on the head = to come to the right conclusion. For example: "You always hit the nail on the head!"

- In the black = to be prosperous. For example: "Very nice! Today you are in the black!"

- To a " $T "$ = perfectly, exactly. For example: "Your answer was really to a " $T$ "!!"

- Keep one's nose to the Grindstone = to continue to work hard without rest. For example: "You have good results! You're keeping your nose on the Grindstone!"

- Know the ropes = to know how to handle the task. For example: "You always know the ropes!"

- Shot in the arm = something that renews people's interest or excites them. For example: "Your report was a shot in the arm for everybody! Thank you!"

- Spring something on someone = to surprise someone with something. For example: "You sprang good news on me!"

- Sweat blood = to put out a great deal of effort. For example: "You really sweated blood!"

The teacher can also use jargon and spoken vocabulary to express praise. Example:

- Bully for you! (colloquial) = well done!

- Capital (colloquial) = great!

- Full marks to someone = glory to anyone!

- Good egg! = good!, great!

- Good for somebody! = well done! Bravo!

- Good thinking! = good thought!

- High marks to someone = glory to anyone!

- Hurray! = glory! Hurray!

- Well done! = bravo !, well done! fine!

- They are just! = true !, correct! exactly!
- Just the thing (colloquial) = just what you need!

- That's more like it! (colloquial) = better!

- That's a good one! = well done!

- That's the idea (colloquial) = that's the idea!

- That's it (colloquial) = just like that! right!

- That's right (colloquial) = correct!

- That's what I call (colloquial) = this is how I ...!

- There is no mistake about it! = true! Undoubtedly!

- Very good = very good!

- Very well = very good!

According to a grammatical point of view, speech acts of praising are expressed by one and two phrase, which can be described by the following formulas:

- (Very) + Adjective, for example: very nice, very good, very interesting.

- Subject + be + Adjective, for example: that's correct, that's incredible, that's wonderful, that's great.

- Subject + Verb + Adverb, for example: you tried hard, you prepared properly for today.

- Subject + Verb + Noun / Gerund, for example: I like your reading, I liked your stories.

The most frequency structural type of speech acts of praising is: (Very) + Adjective.

The grammatical time of speech acts of praising can be not only present but also past. Example:

- Teacher: It was great!

- Teacher: I liked your English intonation!

- Teacher: It was nicely done. I liked your answers!

- Teacher: You worked very hard at home as I see because your answer was much better than at the previous lesson.

- Teacher: Your story was very interesting! Thank you very much.

Usually speech acts of praising are addressed to another person, for example:

Teacher: You were great!

Teacher: Your tempo was ok. I liked it!

Teacher: Your translation was wonderful!

They can also be addressed to a third (missing) person, for example:

Teacher: Although, Max is not here, his work is the best one in your group!

Teacher: Kate appeared to be the cleverest one. Only the right tense form was used!

In terms of describing the speech acts of lexical critique, the most common words and phrases that make up these types of speech acts in English pedagogical discourse are: fear, hope, worry, try, advise / advice not done, for example:

Teacher: I advise you to read more. I don't like your reading.

Teacher: It's a pity, but I should say that the work isn't done in a proper way!

Teacher: You've made the same mistake again! Try to be more attentive!

Modal verbs are widely used to express speech acts of criticism in English pedagogical discourse: have to, must, need, will (should), can (could), for example:

Teacher: I should say that the work is not done in a proper way!

Teacher: What? Haven't you done the homework for today? I could never expect this from you!

Teacher: You must use articles all the time! 
Speech acts of critics are diverse; there is no vocabulary behind them. The teacher may use colloquialisms and idioms to express criticism. The following speech acts of critics should be distinguished by the method of dictionary survey [3, p. 87] (3752 units):

Half the battle $=$ half the work or effort.

Half baked = poorly planned, poorly planned.

Hold one's tongue = to refrain from speaking.

In the lurch = in a bad situation and unable to proceed.

In the same boat = in the same bad situation.

Then have the last laugh = to get revenge on someone who thinks he has been cleverer.

No skin off someone's nose = it has no effect on someone.

Once in a blue moon = very, very rarely.

Talk someone's ear off = to fight someone with one's long-winded talk.

Talk through one's hat $=$ to talk nonsense.

Third-rate $=$ poor quality.

Stonewall = to avoid answering a question directly by being deliberately vague about it, or by talking a lot but not saying anything meaningful, syn: beat around the bush.

Grammatically, the speech acts of criticism are expressed in complex and compound types of sentences, for example:

Teacher: I hope you do the task much better next time.

Teacher: You'll try next time, but you failed today.

Teacher: Your work is well done but not for this case.
Speech acts of criticism can be expressed not only in affirmative but also interrogative sentences, for example:

Teacher: You didn't manage to do the task. What are you going to do so far?

Teacher: What? Haven't you done the homework for today? I could never expect this from you.

Teacher: In what way are you going to correct your mistakes?

Conclusion. In conclusion, there is no specific vocabulary for expressing speech acts of praising and criticism; synonyms, slang, colloquialisms, idioms are widely used. The teacher can also use jargon and colloquial vocabulary to express praise and criticism. Grammatically, the speech acts of praising are expressed by simple or complex sentences, the speech acts of criticism are expressed in complex and compound types of sentences. It is important for a pupil to receive the stimulation from praising and criticism. The illocutionary power of praise is based on the arousal of positive emotions, that is why speech acts of praising embody confidence, create a pleasant mood, increase responsibility. The illocutionary power of speech acts of criticism is based on the arousal of negative emotions in a pupil, which can give rise to his motivation for self-improvement and knowledge improvement.

For further research, we recommend to explore the linguistic and cultural features of speech acts of praising and criticism, namely the variety of vocabulary and grammar use in speech acts of praising and criticism in modern English pedagogical discourse.

\section{REFERENCES}

1. Batsevich F. S. Fundamentals of community linguistics // K.: $\mathrm{VCz}$ «Akademi ya», 2004. $342 \mathrm{p}$.

2. Karasik V. I. About the types of discourse // Language personality: institutional and personal discourse. Volgograd, 2000. P.5-19.

3. Medvedev A. M. English-Ukrainian-Russian Dictionary of Pragmatic Idioms // K.: Noj, 1992. 490 p.

4. Nochevich M.N. Culture and Ethics of Communication // M: Prosveshhenie, 1995. $192 \mathrm{p}$.

5. G. Pocheptsov. On the communicative typology of the addressee // Speech acts in linguistics and methodology. Collec-

tion of scientific papers. Pyatigorsk: izd-vo PGPIIY, 1986. P. 10-17.

6. Austin J.L. How to Do Things with Words // Oxford: At the Clarendon Press, 1962. 166 p.

7. Littlewood W. Communicative language teaching; An introduction // New York: Cambridge University Press, 1981. P.37-40.

8. Searle J. R. Speech Acts // London: Cambridge University Press, 1970. 204 p. 